\title{
SOVIET-CUBAN MESSAGES DURING THE MISSILE CRISIS: CONTROLLING AN ALLY
}

\author{
Zasoba le. \\ Ph.D. Student of the Department of Sociology \\ UMass Boston, Massachusetts, USA
}

The Cuban Missile Crisis, referred to as the Caribbean Crisis in the Soviet Union (Карибский Кризис) and the October Crisis in Cuba, is one of the most famous events of the Cold War. A large number of primary source documents are available for study. The U.S. government has released internal material and much of the official communications between the parties, and the Soviet Union has also released a significant number of documents (mostly during Gorbachev's "Glasnost" ("гласность") program in the 1980's). However, much of the historical analysis that has emerged from this material focuses on: the amount of "blame" that should be assigned to each side, technical discussions regarding the level of risk that there could have been a nuclear war, who "won" and who "lost," and the extent to which President Kennedy's actions may have been mythologized after his assassination. While these themes are important, the event also represents a clear example of the major powers in the Cold War using smaller countries to bear the biggest risks of their global strategies. This paper argues that messages that were sent between the Soviet and Cuban governments at the time show that the Soviets engaged with the Cuban leaders only to the extent that they could control their actions, and that they excluded them from critical decisions. The paper also demonstrates that messages sent between the key Soviet figures in the crisis, later interviews, memoirs and biographies provide insight into the Soviet leadership's justifications for their colonial practices.

The United States and the Soviet Union had come to a situation where one believed the other might actually launch a pre-emptive strike if it could gain an advantage. The U.S. and Soviet Union were engaged in constant conflicts throughout the 1940's and 1950's. 1960 was an election year in the United States, so its hostile actions against Cuba escalated throughout the year, with plots to assassinate Fidel Castro and a trade embargo. Late in the year, Cuba and the Soviet Union issued a statement of solidarity and the Soviets began to supply conventional weapons to Cuba. However, there was no move to put Soviet nuclear missiles in Cuba in 1961. Khrushchev's reason for this was a belief that the U.S. would invade Cuba immediately if he took such an action. The plan to deploy the missiles could have been publicly announced, as it was legal under international law. The decision to deploy the weapons secretly is more evidence that the Soviets thought it was likely that news of such a plan would trigger an invasion. Castro and his inner circle were agreeable. In an interview he gave to PBS in 1985, Fidel Castro claimed that the Cubans' acceptance of the Soviets' missile plan was based on their belief that American invasion was likely unavoidable. However, he also claimed that he was motivated by a desire to help the Soviet Union achieve balance with the U.S. in the global nuclear competition. This agreement did not guarantee Castro equal partnership with the Soviets. The final deal involved stationing the missiles in Cuba, under full Soviet control. The mistrust between the allies began at this early stage. During a meeting to finalize their agreement, Che Guevara had suggested that the plan be made public and Khrushchev had refused. He even refused to sign his name to the treaty, to preserve the option to deny everything if the Cubans proceeded with a unilateral announcement.

Soviet ships with nuclear missiles began to arrive in Cuba. A U.S. plane captured proof of the nuclear missiles in Cuba on October $14^{\text {th }}$, and Kennedy announced the crisis to the public on October $22^{\text {nd }}$. Tensions rose rapidly, so that four days later Castro wrote a letter to Khrushchev, assuring him that Cuban people will confront the aggressor "heroically". On the same day, Khrushchev sent a secret message to Kennedy offering a resolution to the crisis. By October $27^{\text {th }}$ the Soviet Union had finalized an agreement with the U.S. for the withdrawal of its missiles from Cuba, including an agreement to allow on-site inspections in Cuba. Most importantly, Castro first became aware of this agreement from the public announcements that were made by Khrushchev and Kennedy on October $28^{\text {th }}$. Khrushchev also sent a letter to Castro on the $28^{\text {th }}$, and its tone makes it clear that he considered Castro's position to be that of a "little brother" whose emotions and feelings should be soothed, but one who should not expect a decision-making role. Khrushchev's letter goes on to warn Castro against any action that might lead to a reanimation of the crisis. Referring to the shooting down of a U.S. U2 spy plane on the $27^{\text {th }}$, Khrushchev states that this episode was the result of "senseless" provocation by militarists in the Pentagon who still hoped for an excuse to invade. In addition to the firm "advice" that Castro should allow U.S. military planes 
to violate his airspace, it is possible to infer a threat in the letter's subtext. Khrushchev implied that the Soviet Union would not risk a global nuclear war to defend Cuba from invasion if it had the excuse that the invasion had been sparked by unstable elements in the U.S. or in Cuba. The warning in Khrushchev's letter concerning shooting down the U.S. spy plane may have been particularly offensive to Castro. Although, Cuban anti-aircraft personnel had been instructed to fire on American planes to protect the Soviet missile sites, the weapon that had hit the U2 plane was a Soviet-controlled surface-to-air missile. In Castro's response letter to Khrushchev he expresses his rationale. He also refers to the public statement he had issued earlier in that day, in which he had criticized the U.S. promise not to invade Cuba as inadequate. Castro signs off with a notice that he is opposed to inspections. Further messages from October $30^{\text {th }}$ and $31^{\text {st }}$ are remarkable because the first captures Khrushchev's early attempts to frame the entire crisis for history and for his communist audiences, and the second presents Castro's view that the entire enterprise had been futile if the Soviet Union was unwilling to stand its ground. Khrushchev's letter is full of paternalism, he writes that he understands the bitterness that "some" Cubans might feel. Khrushchev refers to a conflict between superpowers in "the Caribbean zone," this emphasizes that Cuba's interests were subordinate to the Soviet Union's regional strategy. Castro rebuts several of Khrushchev's excuses by arguing that backing down was not the appropriate reaction to the possibility of an imminent U.S. attack, by clarifying that he was not consulted at all about the decision to withdraw the missiles, and by stating that many (not "some") Cubans were feeling "unspeakable bitterness and sadness" about the sudden Soviet decision. Castro demonstrated that he understood that the only strategic value of putting missiles in Cuba was as a deterrent against a strike against the U.S.S.R. A message from the Soviet Foreign minister Gromyko to Mikoyan on November $1^{\text {st }}$ detailed how the Cubans should be pressured to soften their "no inspections" position despite the loss of face this would cause them.

Even while the Soviet-Cuban negotiations on the inspections were proceeding, the Soviet leaders were keeping new secrets from their allies. Later decision to remove weapons were made before discussing the issue with the Cubans. The frustrations that this created were evident during Mikoyan's conversation with Castro and the rest of the Cuban leadership on November $22^{\text {nd. }}$ Castro repeated his argument that the Soviets should have kept the strategic missiles in Cuba. The Mikoyan-Castro dialogue serves as evidence of the highly skewed nature of Soviet-Cuban relations and the Soviets' sense that they did not need justification for their colonial practices. Castro had to listen to public statements by Kennedy to acquire up-to-date information about the weapons that remained in his country. After confirming that the tactical missiles were still in Cuba, that they were not technically part of the Soviet's agreement with the U.S. and that the U.S. was not aware of them Mikoyan delivered the news that the Soviets had decided to remove these as well. He explained that there was a law that prevented the transfer control of any nuclear weapons to another country (this was a lie), and that the Soviets intended to withdraw all of their troops from Cuba once the Cuban military had been trained to use the conventional weapons they were leaving behind.

Returning to the question of Soviet justifications, the ambassador's interpretation of the situation gives insight into the Soviet colonial discourse. The Cubans were portrayed as wild children, but wellmeaning and smart, and the Soviets were portrayed as patient parents. Ambassador Beck reports that Mikoyan had characterized the Cuban leaders as young, honest people who were true to the revolution and who were deserving of respect, trust, and appreciation. However, a large part of the Ambassador's message is dedicated to a description of the Cubans' unorthodox path to Marxism, and criticism of the slow pace of development of the Cuban Communist party apparatus and the Cubans' belief that their revolution was one of "three great revolutions" (China's for Asia, the Soviets' for Europe, and Cuba for Latin America).

In conclusion, for fifty-eight years since the Cuban missile crisis, the world did not experience nuclear wars. This outcome has allowed a self-congratulatory narrative to grow regarding the courageous and pragmatic actions of both the U.S. and Soviet leaders. The implication of this narrative is that only the highly tested, and "serious" leaders of superpowers, can be trusted to be stewards of nuclear weapons. In contrast, this way of thinking concludes that the leaders of smaller countries (who have less to lose - in total, but not in proportion) are more likely to choose "honorable destruction" as long as they might inflict asymmetrical damage on their enemies. The dialogues between the protagonists of the Cuban missile crisis demonstrate that there were two big truths. The first truth is that the Cubans could not be trusted with nuclear weapons, and that efforts to limit the proliferation of nuclear weapons have been important. The second truth is that the leaders of the superpowers were just lucky. Like the great powers before WWI, The U.S. and Soviet leadership in the Cold War believed that global domination was their right. This imperialistic attitude was disguised as a defense of God-given human freedom (by the U.S.) or as the result of an inevitable process of social evolution (by the Soviet Union). The U.S. put nuclear missiles in Turkey to protect democracy, and the Soviets said that they put nuclear missiles in Cuba to: a) counter the U.S. missiles in Turkey; b) protect Cuba; c) advance the global socialist project; or d) "put a hedgehog in the Americans' pants".

Key words: cold war leadership, Cuban missile crisis, Caribbean crisis, Soviet-Cuban relations, N. Khrushchev, F. Castro, J. Kennedy.

ВІСНИК НТУУ «КПІ». Політологія. Соціологія. Право. Випуск 4 (44) 2019 
The Cuban Missile Crisis, referred to as the Caribbean Crisis in the Soviet Union (Карибский Кризис) and the October Crisis in Cuba, is one of the most famous events of the Cold War. A large number of primary source documents are available for study - the U.S. government has released internal material and much of the official communications between the parties, and the Soviet Union has also released a significant number of documents (mostly during Gorbachev's "Glasnost" ("гласность") program in the 1980's). However, much of the historical analysis that has emerged from this material focuses on: the amount of "blame" that should be assigned to each side, technical discussions regarding the level of risk that there could have been a nuclear war, who "won" and who "lost," and the extent to which President Kennedy's actions may have been mythologized after his assassination [30]. While these themes are important, the event also represents a clear example of the major powers in the Cold War using smaller, dependent, countries to bear the biggest risks of their global strategies. This paper argues that messages that were sent between the Soviet and Cuban governments at the time show that the Soviets engaged with the Cuban leaders only to the extent that they could control their actions, and that they excluded them from critical decisions. The paper also demonstrates that messages sent between the key Soviet figures in the crisis, and later interviews, memoirs and biographies provide insight into the Soviet leadership's justifications for their colonial practices.

To begin with, when Soviet leader Khrushchev developed the plan to place nuclear missiles in Cuba in April of 1962 he discussed his plan with a only a small number of people [30]. These included First Deputy Chairman Anastas Mikoyan, Foreign Minister Andrei Gromyko, Defense Minister Rodion Malinovsky, Presidium (Politburo) Member Frol Kozlov, and Commander of the Strategic Rocket Forces Sergei Biryuzov. Khrushchev's idea came during a period of intense strategic friction between the U.S. and the Soviet Union. A U.S. spy plane had been shot down over Russia in 1960, The Berlin wall was built in 1961, and U.S. missiles had been placed in Turkey and Italy [11]. Despite the fact that the Soviet Union had been first to launch an artificial satellite ("Sputnik 1" in 1957) by 1961, the United States had a greater capacity to launch intercontinental nuclear missiles [13]. The United States also had an advantage in its ability to launch missiles from submarines, and its allies France and the U.K. also had nuclear weapons. Khrushchev had been travelling in Odessa, before he returned to Moscow and announced his idea to Mikoyan and the others. Mikoyan's son speculates that the chairman looked out across the Black Sea towards the dangerous missiles in Turkey, when it occurred to him that Castro's Cuba represented a real opportunity to reduce America's nuclear weapon advantage [30]. As it will be discussed below, the idea of a Soviet missile deployment in Cuba had been mentioned by both Khrushchev and Robert Kennedy as early as the beginning of 1961, but serious planning did not begin until after Khrushchev's April 1962 holiday [11].

Furthermore, it is important to examine how the United States and the Soviet Union had come to the situation where one believed the other might actually launch a pre-emptive strike if it could gain an advantage. From a practical perspective, the condition of the two countries' nuclear arsenals was primitive: there were a small number of bulky and unreliable weapons on each side, and military planners could describe scenarios in which a first strike might destroy enough of the other side's weapons so that their weak defensive response could lead only to total destruction [18]. In other words, it was still possible to believe that one side could be forced to surrender. While the certainty of mutually assured destruction may not have been established firmly by 1962 , it is also true that either side would only have a few minutes to act if it became confident of an advantage, and it would have had to launch a massive and morally horrific attack. The Cuban missile crisis was a real test of these questions for the leaders and military strategists on both sides; and, although intense nuclear weapons (and missile-defense) competition has continued, the outcome suggests that it taught the nuclear powers that winning a nuclear war was already almost impossible. This process of moving missiles around on the earth to establish balance between great powers is similar to the troop movements that countries used to threaten each other in the period before World War I. In fewer than fifty years humankind went from moving thousands of armed people around by trucks, trains and horses to a situation in which a very small number of leaders played a game of speed-chess with millions of lives at stake over perceived disagreements about political philosophies.

The leaders of the United States and the Soviet Union saw each other as mortal adversaries, despite the fact that both countries were created through the rejection of monarchy and both claimed to be anti-imperialist. The two countries were also the main forces behind the defeat of fascism and racism in World War II. However, they were engaged in constant violent conflicts throughout the 1940s and 1950's. For example, they supported different sides in the Korean war and Chinese revolution, and subjugated smaller countries that threatened to join the other side (e. g. Khrushchev's invasion of Hungary, the elimination of Congo's Patrice Lumumba by Eisenhower's CIA). Considering Cuba's strategic location, it is not surprising that the Americans and the Soviets would have had their eyes on the island during its long revolution and after Fidel Castro came to power, in January 1959. It is perhaps more difficult to understand why it was more 
than a year before the Soviet Union and Cuba established diplomatic relations in May 1960. According to Khrushchev's son Sergei: "At the beginning of 1959 the Soviet leaders could hardly imagine any fate that might link Moscow and Havana. No specialists in the Central Committee, much less Father, even knew much about Latin America. <...> Neither the Communist Party Central Committee's International Department, KGB intelligence, nor military intelligence had any idea who Castro was or what he was fighting for. Father advised them to consult Cuba's Communists; they reported that the newcomer was a representative of the haute bourgeoisie and working for the CIA" [22].

Despite this report on the Soviet leadership's apparent distrust of Castro, the two great powers were uncharacteristically hesitant about taking decisive action in Cuba.

1960 was an election year in the United States, so its hostile actions against Cuba escalated throughout the year, with plots to assassinate Fidel Castro and a trade embargo [11]. Late in the year, Cuba and the Soviet Union issued a statement of solidarity and the Soviets began to supply conventional weapons to Cuba. However, there was no move to put Soviet nuclear missiles in Cuba in 1961. Khrushchev's reason for this was, apparently, a belief that the U.S. would invade Cuba immediately if he took such an action. In fact, during his January 1961 speech to the Cuban Embassy in Moscow he warned that the U.S. was planning to use a lie about Soviet missiles in Cuba as a pretext for invasion. Even after the failure of the U.S. supported Bay of Pigs invasion by Cuban exiles, the conventional wisdom in both the Soviet Union and the U.S. was that a full-scale invasion of Cuba could come at any time. Indeed, planning for an invasion (code named "operation Mongoose") was active [5]. The following exchange regarding Cuba between U.S. president John Kennedy and Alexei Adzhubei occurred during a breakfast meeting at the White House in March 1962: "Kennedy hit his fist on the table and said: Once I summoned Allen Dulles and rebuked him. I said to him: "Iearn from the Russians. When they had a tough situation in Hungary, they put an end to the conflict in just three days. When they didn't like the events in Finland, the president of that country went to meet with the Soviet Premier in Siberia, and everything was worked out. And you, Dulles, couldn't do a thing".

I answered the President: "With regard to Hungary, your analogy with Cuba is entirely untenable. With regard to Finland, well maybe this is the case, which should make the United States aware that they need to learn to respect Cuba. After all, we respect Finland. Even though capitalist elements exist within it, the president of a bourgeois government retains good relations with the Soviet Union" [1].

Although Adzhubei rejected Kennedy's pairing of Hungary with Cuba, the Soviets understood the practical implications of the President's Statement. Cuba was located less than 100 miles from Florida, and the U.S. had had a military base at Guantanamo Bay since 1898 (it was established during the Spanish-American War) [12].

While Khrushchev knew that the U.S. could crush Castro's army in Cuba as quickly as he had invaded Hungary, in the end, he decided to take the risk. The plan to deploy the missiles could have been publicly announced, as it was legal under international law to place these types of weapons on the territory of a consenting allied country (as the U.S. did in case of Turkey and Italy). So, the decision to deploy the weapons secretly is more evidence that the Soviets thought it was likely that news of such a plan would trigger an invasion. Sergo Mikoyan confirms this: "Yes, yes, his approach was either not to do it at all or if you do it, secretly of course. Otherwise it will not be permitted by the United States because of the American fleet and the geographical conditions for Cuba" [17].

In addition, Mikoyan's son explains that his father was initially against the plan on the grounds that it was too dangerous, that Fidel Castro would not agree, and that the operation could not be kept secret [30]. But Anastas Mikoyan's objections were overruled after a Soviet diplomatic and military delegation visited Cuba at the end of May 1962. The diplomats found that Castro and his inner-circle (his brother Raul, Che Guevara, Osvaldo Dorticos and Blas Roca) were agreeable, and the military team concluded that they could keep the deployment hidden until it was a "fait-accompli" [30]. In an interview he gave to PBS in 1985, Fidel Castro claimed that the Cubans' acceptance of the Soviets' missile plan was based on their belief that American invasion was likely unavoidable. However, he also claimed that he was partially motivated by a desire to help the Soviet Union achieve balance with the U.S. in the global nuclear competition [6].

Obviously, this agreement did not guarantee Castro equal partnership with the Soviets. The final deal involved stationing the missiles in Cuba, under full Soviet control, and preparations began almost immediately in July [11]. The mistrust between the allies beganat this early stage. Apparently, during a meeting to finalize their agreement, Che Guevara had suggested that the plan be made public and Khrushchev had refused. He even refused to sign his name to the treaty, to preserve the option to deny everything if the Cubans proceeded with a unilateral announcement [11]. Although, the Soviet-dominated nature of this alliance is not surprising from today's perspective, and Soviet reluctance to be pulled into a global nuclear war over Cuba was undeniably reasonable; it is still impressive to consider that Khrushchev demonstrated a near complete disregard for Castro's leadership at the apex of the Crisis. 
After a summer of preparations and construction, including defensive SAM missile installations and facilities meant to conceal the strategic missiles; Soviet ships with nuclear missiles began to arrive in Cuba in mid-September. A U.S. spy plane captured proof of the nuclear missiles in Cuba on October $14^{\text {th }}$, and Kennedy announced the crisis to the public on October $22^{\text {nd }}$. At that point tensions rose rapidly, so that four days later Castro wrote a letter to Khrushchev, stating:

"Dear Comrade Khrushchev:

From Our Analysis of the situation and the reports in our possession, I consider that the aggression is almost imminent within the next 24 to 72 hours.

There are two possible variants: the first and likeliest one is an air attack against certain targets with the limited objective of destroying them; the second, less probable although possible, is invasion. I understand that this variant would call for a large number of forces and it is, in addition, the most repulsive form of aggression, which might inhibit them.

You can rest assured that we will firmly and resolutely resist attack, whatever it may be. The morale of the Cuban people is extremely high and the aggressor will be confronted heroically" [8].

On the same day that this message was sent, Khrushchev sent a secret message to Kennedy offering a resolution to the crisis [30], and by October $27^{\text {th }}$ the Soviet Union had finalized an agreement with the U.S. for the withdrawal of its missiles from Cuba (including an agreement, in principle, to allow on-site inspections in Cuba). Most importantly, Castro first became aware of this agreement from the public announcements that were made by Khrushchev and Kennedy on October $28^{\text {th }}$. Khrushchev also sent a letter to Castro on the $28^{\text {th }}$, and its tone makes it clear that he considered Castro's position to be that of a "little brother" whose emotions and feelings should be soothed, but one who should not expect a decision-making role. The following excerpt from the letter illustrates this claim:

"Dear Comrade Fidel Castro:

Our October 27 message to President Kennedy allows for the question to be settled in your favor, to defend Cuba from an invasion and prevent war from breaking out. Kennedy's reply, which you apparently also know, offers assurances that the United States will not invade Cuba with its own forces, nor will it permit its allies to carry out an invasion. In this way the president of the United States has positively answered my messages of October 26 and 27, 1962.

We have now finished drafting our reply to the president's message. I am not going to convey it here, for you surely know the text, which is now being broadcast, over the radio.

With this motive I would like to recommend to you now, at this moment of change in the crisis, not to be carried away by sentiment and to show firmness. I must say that I understand your feelings of indignation toward the aggressive actions and violations of elementary norms of international law on the part of the United States <...” [20].

Khrushchev's letter goes on to warn Castro against any action that might lead to a reanimation of the crisis. Referring to the shooting down of a U.S. U2 spy plane [2; 3] on the $27^{\text {th }}$, Khrushchev states that this episode was the result of "senseless" provocation by militarists in the Pentagon who still hoped for an excuse to invade. In addition to the firm "advice" that Castro should allow U.S. military planes to violate his airspace, it is possible to infer a threat in the letter's subtext. By bringing up the idea of a divided U.S. leadership, with unreasonable Pentagon "hawks" and a more reasonable Kennedy, Khrushchev implied that the Soviet Union would not risk a global nuclear war to defend Cuba from invasion if it had the excuse that the invasion had been sparked by unstable elements in the U.S. or in Cuba. In fact, on the $27^{\text {th }}$, the Russian Defense minister Malinovsky sent the following coded message to the commander of the Soviet forces in Cuba (General Issa A. Pliyev): "We categorically confirm that you are prohibited from using nuclear weapons from missiles, FKR [cruise missiles], "Luna" and aircraft without orders from Moscow Confirm receipt" [25].

The fact that this message included the FKR and "Luna" tactical short-range weapons shows that the Soviet leadership had decided to separate the possibility of an attack against Cuba from any certainty of a Soviet nuclear response. Also, the warning in Khrushchev's letter concerning shooting down the U.S. spy plane may have been particularly offensive to Castro because, although Cuban anti-aircraft personnel had been instructed to fire on American planes (to protect the Soviet missile sites), the weapon that had hit the U2 plane was a Soviet-controlled surface-to-air missile [11]. In Castro's response letter to Khrushchev, he expresses his rationale for shooting at U.S. planes to protect the nuclear missiles. He also refers to the public statement he had issued earlier in that day, in which he had criticized the U.S. promise not to invade Cuba as inadequate. Castro signs off with a notice that he is opposed to inspections and bland (perhaps, even ironic) words of gratitude: "<... I also wish to inform you that we are in principle opposed to an inspection of our territory. I appreciate extraordinarily the efforts you have made to keep the peace and we are absolutely in agreement with the need for struggling for that goal. If this is accomplished in a just, solid and definitive manner, it will be an inestimable service to humanity" [9]. 
An apparent gulf between the Soviet's attempts to justify its imperialistic attitudes and the Cuban vision could be illustrated by a few messages between Khrushchev and Castro. Indeed, these messages from October $30^{\text {th }}$ and $31^{\text {st }}$ are remarkable because the first captures Khrushchev's early attempts to frame the entire crisis for history and for his soviet and allied communist audiences, and the second presents Castro's view that the entire enterprise had been futile if the Soviet Union were unwilling to stand its ground (including the threat of an automatic nuclear response to an attack on Cuba). Khrushchev's letter is full of paternalism, reminds one of a lecture in which the lecturer explains the obvious, while writing that he understands the bitterness that "some" Cubans might feel about his abrupt change of heart: "<...> The conflict in the Caribbean zone which, as you well realize, was characterized by the clash of two superpowers and the possibility of being it transformed into a thermonuclear world war <..." [21].

It is significant that Khrushchev refers to a conflict between superpowers in "the Caribbean zone", since this emphasizes that Cuba's interests were subordinate to the Soviet Union's regional strategy. Of course, Khrushchev also argues that the decision to withdraw the missiles was, in part, a desire to see the U.S. blockade ended as soon as possible, and a reaction to a "consultation" with Castro (the warning in Castro's October $26^{\text {th }}$ message that an invasion was imminent). One additional excuse that Khrushchev mentions is that a U.S. strike could have easily taken out the Soviet missiles on Cuba. This is a strange admission, since it reveals that the plan was not well conceived in the first place. In the end, after producing a somewhat incoherent list of excuses, the directive tone returns and Khrushchev informs Castro that: "As the talks to settle the conflict get underway, I ask you to send me your considerations. For our part, we will continue to report to you on the development of these talks and make all necessary consultations" [21].

In other words, Castro was informed that Khrushchev was always and remained in charge.

Castro's reply to this message demonstrates a much clearer analysis of the situation. Castro rebuts (politely) several of Khrushchev's excuses by arguing that backing down was not the appropriate reaction to the possibility of an imminent U.S. attack. By clarifying that he was not consulted at all about the decision to withdraw the missiles, and by stating that many (not "some") Cubans were feeling "unspeakable bitterness and sadness" about the sudden Soviet decision. In a more emotional passage, Castro explains to Khrushchev that a sense of "brotherhood" had grown between the Soviet and Cuban soldiers as they stood together in Cuba but that: "Countless eyes of Cuban and Soviet men who were willing to die with supreme dignity shed tears upon learning about the surprising, sudden and practically unconditional decision to withdraw the weapons" [10].

Apparently, Castro's description of Cuba's potential place in the Soviet global nuclear strategy included the premise that Pentagon "hawks" were considering the possibility of pre-emptive nuclear strikes against the Soviets and that the missiles in Cuba provided protection against this type of attack: "Everyone has his own opinions and I maintain mine about the dangerousness of the aggressive circles in the Pentagon and their preference for a preventive strike. I did not suggest, Comrade Khrushchev, that in the midst of this crisis, the Soviet Union should attack, which is what your letter seems to say; rather, that following an imperialist attack, the USSR should act without vacillation and should never make the mistake of allowing circumstances to develop in which the enemy makes the first strike against the USSR" [10].

In this passage, Castro demonstrated that he understood that the only strategic value of putting missiles in Cuba was as a deterrent against a strike by the U.S. This view is consistent with the rationale that the Soviet leaders had discussed while planning the mission. So, Castro made a logical case that the Soviet decision to withdraw the missiles was inconsistent with the main reason for installing them in the first place. Castro was firm and clear in his message, which questioned Khrushchev's logic and courage explicitly, but he mentioned that he was aware that such criticism could only be appropriate in the context of a "very personal message". Castro was also careful to add apologetic and flattering notes: "< .. > following the dictates of my conscience as a revolutionary duty and inspired by the most unselfish sentiments of admiration and affection for the USSR, for what she represents for the future of humanity. $<\ldots>$ I spoke not as a troublemaker but as a combatant from the most endangered trenches" [10].

Based on his correspondence with Khrushchev, Castro understood that the Soviet leader would follow through on his agreement to dismantle and withdraw its strategic nuclear weapons from Cuba. However, he had already announced that he would not allow inspections. A message from the Soviet Foreign minister Gromyko to Mikoyan on November $1^{\text {st }}$ detailed how the Cubans should be pressured to soften their "no inspections" position despite the loss of face that this would cause them. Gromyko advised Mikoyan to warn the Cubans that delaying inspections was likely to delay the lifting of the U.S. blockade on Cuba, putting perishable cargo at risk as it sat on Soviet ships that could not dock in Cuba: "I think that these concerns should be borne in mind when you are presenting our case to Castro. This does not mean, of course, that they should be expressed literally and explicitly. But you must make him clearly understand that we are worried by the unreasonable position that our Cuban comrades have been forced to take" [14]. 
Mikoyan's held meetings on the question of inspections with Castro and the other Cuban leaders over the next ten days. Mikoyan offered the idea of U.N. inspections, he had discussions about multi-lateral inspections (i. e. parallel inspections of anti-Cuban training camps in Guatemala and the U.S.), and he even suggested that the missiles could be inspected once they had been loaded onto Soviet ships (still in Cuban ports) [28]. During his negotiations over inspections, Mikoyan also continued to pressure the Cubans to accept the Soviet explanation for why the "offensive" nuclear weapons were being withdrawn, centered on the idea that the weapons could be easily eliminated in a first strike (as had been argued in Khrushchev's October $30^{\text {th }}$ letter). Mikoyan's accounts of these conversations [27], suggest that the Cubans accepted this explanation. However, it did nothing to resolve their desire for a Soviet declaration that a U.S. action to eliminate the Soviet missiles in Cuba would be considered a first strike on the USSR itself. In any case, the Cubans were firm and did not agree to inspections. Despite this fact, the U.S. lifted its blockade on November 20 $0^{\text {th }}[11]$.

Even while the Soviet-Cuban negotiations on the inspections were proceeding, the Soviet leaders were keeping new secrets from their allies. Coded memos from the secretary of Defense to the commander of Soviet troops in Cuba [26] show that the Soviets were still undecided on whether or not to keep tactical nuclear weapons in Cuba (the FKR short range missiles and nuclear bombs for IL-28 planes). Shortly afterwards, the U.S. communicated that it considered the IL-28 planes to be offensive weapons even if they were only armed with conventional bombs, and the Soviets decided to remove them. Again, the decisions were made before discussing the issue with the Cubans [27]. The Soviet justification was that the planes were obsolete anyway. Once again, the Cuban leadership had been excluded from the decision-making process. The frustrations that this created were evident during Mikoyan's conversation with Castro and the rest of the Cuban leadership on November $22^{\text {nd }}$ Castro repeated his argument that the Soviets should have kept the strategic missiles in Cuba; while he stated that he accepted the idea that the missiles lost much of their strategic value once they were discovered, he also complained that the Soviet military had not done enough to conceal them while they were being assembled. This part of the discussion was one of regret by the $22^{\text {nd }}$, since the strategic missiles had already been disassembled. However, the decision on the removal of the IL-28 bombers was a more recent bitter surprise for the Cubans, and Mikoyan had a few additional revelations that would upset them regarding the nuclear-armed tactical missiles (FKRs):

F. Castro: I am still in a bad mood, because some points are still unclear to me. I am concerned, first of all, by Kennedy's statement that all nuclear weapons were removed from Cuba. Has the Soviet Union ever given such a promise? Is it true that all the tactical nuclear weapons are already removed?

A.I. Mikoyan: The Soviet government has not given any promises regarding the removal of the tactical nuclear weapons. The Americans do not even have any information that they are in Cuba.

F. Castro: So then the tactical nuclear weapons are here? And no assurances were given regarding their withdrawal?

A.I. Mikoyan: Not about tactical nuclear weapons.

F. Castro: Therefore, then, the weapons are here?

A.l. Mikoyan: Yes, they are here. They are in Comrade Pavlov's hands. These weapons are not offensive weapons. They can be used in the place of nuclear cannons [29].

This dialogue serves as remarkable evidence of the highly skewed nature of Soviet-Cuban relations and the Soviets' sense that they did not need justification for their colonial practices. From the dialogue, it is clear that Castro had to listen to public statements by Kennedy to acquire up-to-date information about the weapons that remained in his country. After confirming that the FKRs were still in Cuba, that they were not technically part of the Soviet's agreement with the U.S. and that the U.S. was not aware of them Mikoyan delivered the news that the Soviets had decided to remove these as well. He explained that there was a law that prevented the transfer control of any nuclear weapons to another country (this was a lie [30]), and that the Soviets intended to withdraw all of their troops from Cuba once the Cuban military had been trained to use the conventional weapons they were leaving behind.

In their conversation with Mikoyan on November $22^{\text {nd }}$ the Cubans revisited the entire timeline of the crisis. From their point of view, they had willingly accepted the risk of being annihilated as a tripwire that could deter a direct U.S. strike on the USSR. While they appreciated the idea of hosting weapons that could inflict great damage in the event of an attack on Cuba, they were also proud to "do their duty" for the cause of global socialism. In this discussion, they were informed that there was no hope of keeping any form of nuclear weapon on the island, that there would be no permanent Soviet bases in Cuba, that they would have to continue to tolerate U.S. violations of their airspace, and that they could not even count on a formal declaration of an ongoing military alliance. In addition to being left almost defenseless against a future U.S. attack, Cubans had to worry about how the Cuban people would react to their leaders' loss of face. Castro expressed his emotions clearly at one point in the conversation, stating: "What do you think we are? A zero on the left, a dirty rag. We tried to help the Soviet Union to get out of a difficult situation" [29]. 
The November $22^{\text {nd }}$ meeting ended with an exchange of positive wishes, and some praise for specific Soviet military personnel who the Cubans had worked with. They also discussed Mikoyan's plan for a friendly visit with Fidel Castro's brother Raul before departing for New York to complete talks with the U.S. and speak with the Secretary General of the U.N. The extent of the Cubans' unhappiness became clearer after the meeting, when the Cuban leadership stopped communicating with the Soviets and representatives from other Eastern Blok countries. On December 1st 1962, János Beck, the Hungarian ambassador to Cuba, wrote to his foreign minister to report about the Cubans' lack of communication [7].

Returning to the question of Soviet justifications, the ambassador's interpretation of the situation gives insight into the Soviet colonial discourse. The Cubans were portrayed as wild children, but well-meaning and smart, and the Soviets were portrayed as patient parents. Ambassador Beck reports that Mikoyan had characterized the Cuban leaders as young, honest people who were true to the revolution and who were deserving of respect, trust, and appreciation. However, a large part of the Ambassador's message is dedicated to a description of the Cubans' unorthodox path to Marxism, and criticism of the slow pace of development of the Cuban Communist party apparatus and their belief that their revolution was one of "three great revolutions" (China's for Asia, the Soviets' for Europe, and Cuban for Latin America). In addition to the suggestion that Castro's leadership group was too ambitious, ambassador Beck touched on the theme of their supposed impatience, writing that they imagine: " $<\ldots>$ all solutions through great, heroic, revolutionary deeds" [7]. In addition, the Hungarian ambassador's emphasis on the impatience of Cuban leaders echoes what was being said in Moscow to justify the removal of the missiles. Savranskaya reports that Khrushchev defended his decision to retreat at a meeting of the Soviet Presidium on December $3^{\text {rd }}$ [30]. During this meeting, Anastas Mikoyan provided his report on the crisis, and Khrushchev expressed anger at what he described as Castro's willingness to start a nuclear war. While Khrushchev may have been sincerely irritated, it is also true that the plan to place the missiles in Cuba was his own, and its failure made him look weak to his subordinates. Perhaps, Khrushchev's emotions came partially from Soviet internal politics. Since any vulnerability can be fatal for a dictator, there was always an urgent need for damage control. Indeed, Khrushchev was deposed in a coup two years later. Although she acknowledges Khrushchev's desire to shift the blame for the mission's failure to Castro, historian Savranskaya also refers to the Cuban leaders as "revolutionary hotheads", and she writes this: "Khrushchev was already uncomfortable with Castro's impulsiveness and what the Soviet leaders understood as his implied request on October 27 to launch a pre-emptive nuclear strike against the United States if Washington attacked Cuba" [30].

Although this phrase captures the public opinion that Khrushchev and his allies expressed at the time, an opinion embraced by sympathetic chronicle writers like the younger Mikoyan and Savranskaya, it is a very bizarre construction. This becomes evident if one makes a creative substitution to consider a sentence like this: "Kennedy was uncomfortable with the Turkish president's expectation that the U.S. would launch a pre-emptive nuclear strike against the Soviet Union if Moscow attacked Turkey". Clearly, although it would be a first use of nuclear force, such a strike would not be pre-emptive at all from the point of view of the country that had been attacked (and perhaps annihilated), whether Turkey or Cuba! In each case, the weaker "client" country is being asked to bear the risk of hosting nuclear weapons that might provoke an attack, while they receive no protection under the "nuclear umbrella" of their powerful patrons.

In conclusion, for fifty-six years since the Cuban missile crisis, the world did not experience nuclear wars. This outcome has allowed a self-congratulatory narrative to grow regarding the courageous and pragmatic actions of both the U.S. and Soviet leaders [22]. The implication of this narrative is that only the highly tested, and "serious" leaders of superpowers, can be trusted to be "good" stewards of nuclear weapons. In contrast, this way of thinking concludes that the leaders of smaller countries (who have less to lose - in total, but not in proportion) are more likely to choose "honorable destruction" as long as they might inflict asymmetrical damage on their enemies. The dialogues between the protagonists of the Cuban missile crisis demonstrate that there were two big truths. The first truth is that the Cubans could not be trusted with nuclear weapons, and that efforts to limit the proliferation of nuclear weapons have been important. The second truth is that the leaders of the superpowers were no better, they were just lucky. Like the leaders of the great powers before WWI, The U.S. and Soviet leaders in the Cold War believed that global domination was their right. Both were prepared to incite violence and create instability in weaker countries to increase their sphere of control. This imperialistic attitude was disguised as a defense of God-given human freedom (by the U.S.) or as the result of an inevitable process of social evolution (by the Soviet Union). The U.S. put nuclear missiles in Turkey to protect democracy, and the Soviets said that they put nuclear missiles in Cuba to: a) counter the U.S. missiles in Turkey; b) protect Cuba; c) advance the global socialist project; or d) "put a hedgehog in the Americans' pants" [31]. A valid rationale for denying nuclear weapons to small countries is that, with a larger number of countries, it becomes more likely that some country will become unstable or will have an incompetent or evil leadership. In the period from 1962 to the present, the Soviet Union has fallen, leading to a mafia-run Kremlin government. The democratic process has become more corrupt and emotion-driven in the U.S. Therefore, in the long run, there is no country that can be trusted with nuclear weapons. 


\section{Засоба Є. Радянсько-кубинська комунікація під час Кубинської кризи: контроль над союзником}

Кубинська ракетна криза, яку називають Карибською кризою в Радянському Союзі (Карибский кризис) та Жовтневою кризою на Кубі, - одна з найвідоміших подій холодної війни. Велика кількість первинних джерел доступна для вивчення цієї події. Уряд США оприлюднив внутрішні матеріали та значну частину офіційних перемов між сторонами, Радянський Союз також відкрив доступ до значної кількості документів (переважно під час програми М. Горбачова «Гласність» («гласность») у 1980-х рр.). Однак значна частина історичного аналізу, що постає із цього матеріалу, зосереджується на кількості «провини», яку має нести кожна сторона конфрлікту, на технічних дискусіях щодо ризиків ядерної війни, на намаганнях з'ясувати, хто «переміг», а хто «втратив», і на тому, наскільки дії президента Дж. Кеннеді були міфологізовані після його вбивства. Незважаючи на важливість усіх цих тем, подія також є наочним прикладом того, як основні держави холодної війни перекладали найбільші ризики своїх глобальних стратегій на менш потужні країни. У статті наводяться уривки з листування між радянським та кубинським урядами під час кризи. Ці листи свідчать про те, що лідери Радянського Союзу контактували з кубинськими лідерами лише тією мірою, якою вони могли контролювати дії кубинців, не залучаючи тих до прийняття важливих рішень. Стаття такождемонструє, що повідомлення, надіслані ключовими радянськими діячами періоду кризи, а також пізніші інтерв'ю, спогади й біографрії показують, як радянське керівництво виправдовувало свою колоніальну практику.

Сполучені Штати Америки та Радянський Союз потрапили в таку ситуацію, коли одна сторона вважала, що інша зможе насправді завдати ядерного удару, якщо це дасть цій стороні військову перевагу. Обидві держави постійно коноліктували впродовж 1940-х та 1950-х рр. 1960 р. був роком президентських виборів у США, на їх тлі відбувалася ескалація конфлікту з Кубою протягом усього року, у тому числі плани щодо вбивства Фіделя Кастро та встановлення торговельного ембарго. Наприкінці того ж року Куба та Радянський Союз виступили із заявою про солідарність, СРСР почав поставляти на Кубу конвенційну зброю. Важливо, що в 1961 р. не було жодних намагань встановити на Кубі радянські ядерні ракети. М. Хрущов вважав, що в такому разі США негайно вторгнуться на Кубу. Про плани на розміщення ракет можна було публічно оголосити, оскільки міжнародне право не забороняло таке розміщення. Рішення розгортати зброю таємно, скоріш за все, є свідченням того, що радянська влада вважала ймовірним провокування вторгнення. Ф. Кастро та його оточення погоджувалися. В інтерв'ю каналу PBS в 1985 р. Фідель Кастро пояснював, що прийняття кубинцями радянського ракетного плану базувалося на тому переконанні, що американське вторгнення неминуче. Однак він також стверджував, що його мотивувало бажання допомогти Радянському Союзу досягти паритету із США у світовій ядерній гонці. Ця угода не гарантувала Ф. Кастро рівноправне партнерство з радянськими лідерами. Заключна угода передбачала розміщення ракет на Кубі під повним радянським контролем. Недовіра між союзниками почалася на цій ранній стадії. Під час зустрічі щодо доопрацювання домовленостей Че Гевара запропонував оприлюднити план, однак М. Хрущов відмовився. Він навіть відмовився вказувати своє ім'я в договорі, щоб зберегти можливість відступу, якщо кубинці вдадуться до одностороннього розголошення.

На Кубу почали прибувати радянські кораблі з ядерними ракетами. Американський літак отримав докази пересування ядерних ракет на Кубі 14 жовтня, а Дж. Кеннеді оголосив про кризу публічно 22 жовтня. Напруга швидко зростала до того рівня, що через чотири дні Ф. Кастро написав листа до М. Хрущова, запевнивши його, що кубинський народ буде протистояти агресору «героїчно». Того ж дня М. Хрущов відправив таємне повідомлення до Дж. Кеннеді, пропонуючи залагодити ситуацію. До 27 жовтня Радянський Союз уже уклав угоду із США про виведення своїх ракет із Куби та дав згоду на допуск на Кубу інспекцій на місцях. Найголовніше при цьому те, що сам Ф. Кастро вперше дізнався про цю угоду з публічних оголошень, які зробили М. Хрущов та Дж. Кеннеді 28 жовтня. Того ж дня М. Хрущов надіслав листа до Ф. Кастро. 3 огляду на тон листа зрозуміло, що він вважав позицію Ф. Кастро позицією «маленького брата», емоції й почуття якого потрібно враховувати, однак брати участь у рішеннях він не може. У листі М. Хрущов застерігає Ф. Кастро проти будь-яких дій, які можуть призвести до реанімації кризи. Посилаючись на збиття американського шпигунського літака U2 27 жовтня, М. Хрущов заявляє, що цей епізод став результатом «безглуздих» провокацій мілітаристів у Пентагоні, які все ще сподівалися на привід для вторгнення. Окрім твердої «поради» Ф. Кастро дозволити американським військовим літакам порушувати його повітряний простір, у підтексті листа можна побачити загрозу. М. Хрущов, можливо, мав на увазі те, що Радянський Союз не ризикуватиме глобальною ядерною війною, щоб захистити Кубу від вторгнення, особливо якщо в М. Хрущова буде виправдання, що вторгнення викликали нестабільні елементи в США або на Кубі. Попередження в листі М. Хрущова щодо збиття американського шпигунського літака, можливо, було 
особливо образливим для Ф. Кастро. Хоча кубинським повітряним силам доручили вести вогонь по американським літакам, щоб захистити радянські ракетні об'єкти, зброя, яка влучила в літак U2, була радянською ракетою системи «земля-повітря». У відповіді до М. Хрущова Ф. Кастро пропонує своє обґрунтування. Він також посилається на публічну заяву, опубліковану напередодні, у якій вважає обіцянку США не вторгатися на Кубу неадекватною. Ф. Кастро завершує повідомлення твердженням, що він проти інспекцій. Подальші повідомлення від 30 та 31 жовтня визначаються тим, що вони, по-перше, демонструють ранні спроби М. Хрущова сорормулювати кризу для історії та для своєї комуністичної аудиторії, а по-друге, висвітлюють думку Ф. Кастро, який вважав, що вся операція була марною, якщо Радянський Союз буде поступатися американцям. Лист М. Хрущова сповнений патерналізму, він пише, що розуміє ту гіркоту, яку відчувають «деякі» кубинці. М. Хрущов посилається на конфлікт між наддержавами в «Карибській зоні», це фрормулювання підкреслює той факт, що інтереси Куби були підпорядковані регіональній стратегії Радянського Союзу. Ф. Кастро спростовує декілька виправдань від М. Хрущова, стверджуючи, що відступ не є відповідною реакцією на реальну можливість нападу США. Ф. Кастро уточнює, що з ним взагалі не консультувалися щодо рішення про виведення ракет, що більшість кубинців (а не «деякі») відчули «невимовну гіркоту й смуток» із приводу раптового радянського рішення. Ф. Кастро продемонстрував розуміння того, що єдиною стратегічною цінністю в розміщенні ракет на Кубі було стримування США проти удару по СРСР. Повідомлення радянського міністра закордонних справ А. Громико до А. Мікояна 1 листопада детально пояснювало, як на кубинців необхідно чинити тиск, щоб пом'якшити їх позицію «ні інспекціям», незважаючи на вірогідність втрати кубинською владою обличчя.

Навіть під час переговорів із кубинцями про інспекції радянські лідери зберігали нові таємниці від своїх союзників. Пізніше рішення про відвід зброї було прийняте ще до обговорення цього питання з кубинцями. Розчарування, яке це викликало, було очевидним під час розмови А. Мікояна з Ф. Кастро та рештою кубинського керівництва 22 листопада. Ф. Кастро повторив свій аргумент про те, що СРСР мав зберігати стратегічні ракети на Кубі. Діалог А. Мікояна з Ф. Кастро свідчить про сильно викривлений характер радянсько-кубинських відносин. Розмова демонструє позицію радянської сторони, яка не вважала за потрібне виправдовувати свою колоніальну практику. Ф. Кастро доводилося слухати публічні заяви Дж. Кеннеді, щоб отримати актуальну інформацію про зброю, яка залишилася в його країні. Підтвердивши, що тактичні ракети все ще перебувають на Кубі, що вони не є частиною РадянськоАмериканської угоди, що США не знали про них, А. Мікоян повідомив, що СРСР також вирішили їх забрати. Він пояснив, що є закон, який перешкоджає переданню іншій країні контролю над будь-якою ядерною зброєю (це була брехня), і що СРСР мав намір вивести всі свої війська з Куби після того, як кубинські військові навчаться використовувати конвенційну зброю, яку СРСР залишав після себе.

Якщо повернутися до питання про радянські виправдання, то інтерпретація кризи послом Угорщини на Кубі Я. Беком дає розуміння радянського колоніального дискурсу. Кубинці сприймалися як дикі, проте доброзичливі й кмітливі діти, а радянські лідери зображувалися як терплячі батьки. Посол Я. Бек повідомляє, що А. Мікоян характеризував кубинських лідерів як молодих, чесних людей, вірних революції, які заслуговують на повагу, довіру та вдячність. Однак значна частина повідомлення посла присвячена опису неортодоксального шляху кубинців до марксизму, критиці повільних темпів розвитку партійного апарату Куби та переконань кубинців у тому, що їхня революція була однією з «трьох» великих революцій (китайська для Азії, радянська для Європи та кубинська для Латинської Америки).

Наостанок варто зазначити, що 58 років після Кубинської кризи світ не зазнавав ядерних воєн. Цей результат привів до розквіту наративу самозахоплення в розповідях про сміливі й прагматичні дії як американських, так і радянських лідерів. Наслідком цього самозахоплення є віра в те, що володіння ядерною зброєю можна довіряти лише висококваліфікованим і «серйозним» лідерам наддержав. Таке мислення призводить до висновку, що лідери менших країн, яким втрачати менше (кількісно, проте не пропорційно), мають більше шансів обрати «почесне знищення», якщо вони зможуть завдати ворогам асиметричного збитку. Діалоги між основними персонами кубинської ракетної кризи демонструють, що існували дві великі правди. Перша правда полягає в тому, що кубинцям не можна було довіряти ядерну зброю і що зусилля щодо обмеження поширення ядерної зброї були дуже важливими. Друга правда полягає в тому, що лідерам наддержав просто пощастило. Як і великі держави до Першої світової війни, США та радянське керівництво періоду холодної війні вважали глобальне панування своїм правом. Це імперіалістичне ставлення маскувалося як захист даної богом людської свободи (у США) або як результат неминучого процесу соціальної еволюції (у Радянському Союзі). США встановили ядерні ракети в Туреччині для захисту демократії, а СРСР пояснювали розміщення ядерних ракет на Кубі такими причинами: а) протидією американським ракетам у Туреччині; б) захистом Куби; в) просуванням глобального соціалістичного проєкту; г) «підсунути їжака в штани американцям».

Ключові слова: події холодної війни, Кубинська ракетна криза, Карибська криза, радянськокубинські відносини, М. Хрущов, Ф. Кастро, Дж. Кеннеді. 


\section{References:}

1. Adzhhubei A. Memorandum, A. Adzhubei's Account of His Visit to Washington to the CC CPSU (March 12, 1962). URL: https://nsarchive2.gwu.edu/nsa/cuba_mis_cri/620312\%20Adzhubei\%27s\%20 Account.pdf (access date: 29.09.2017).

2. Order authorizing anti-aircraft fire (November 17, 1962). URL: https://nsarchive2.gwu.edu/nsa/cuba_ mis_cri/621117\%20Authorizing\%20Anti-aircraft\%20Fire.pdf (access date: 29.09.2017).

3. Order rescinding authorization to initiate anti-aircraft fire (November 18, 1962). URL: https://nsarchive2.gwu.edu/nsa/cuba_mis_cri/621118\%20Authorization\%20Rescinded.pdf (access date: 29.09.2017).

4. Instructions from CC CPSU Presidium to Mikoyan (November 22, 1962). URL: https:// nsarchive2.gwu.edu/nsa/cuba_mis_cri/621122\%20CPSU\%20Instructions\%20to\%20Mikoyan.pdf (access date: 29.09.2017).

5. U.S. intelligence memorandum - consequences of U.S. military intervention in Cuba (August 8 , 1962). URL: https://www.archives.gov/files/research/jfk/releases/docid-32424897.pdf (access date: 01.10.2017).

6. Interview with Fidel Castro. PBS. 1985. URL: https://www.pbs.org/newshour/show/1985-interviewcastro-spoke-fearing-u-s-invasion (access date: 30.09.2017).

7. Beck J. Telegram "The Essence of Soviet-Cuban Divergences of Opinion" (December 1, 1962). Accessed September 29, 2017. https://nsarchive2.gwu.edu/nsa/cuba_mis_cri/621201\%20Telegram\%20from $\% 20$ Hung.\%20Amb..pdf (access date: 29.09.2017).

8. Castro letter to Khrushchev (October 26, 1962). URL: https://nsarchive2.gwu.edu/nsa/cuba_mis_ cri/621026\%20Castro\%20Letter\%20to\%20Khrushchev.pdf (access date: 29.09.2017).

9. Castro letter to Khrushchev (October 28, 1962). URL: https://nsarchive2.gwu.edu/nsa/cuba_mis_ cri/19621028caslet.pdf (access date: 29.09.2017).

10. Castro letter to Khrushchev (October 31, 1962). URL: https://nsarchive2.gwu.edu/nsa/cuba_mis_ cri/621031\%20Letter\%20to\%20Khrushchev.pdf (access date: 29.09.2017).

11. Chronologies from: The Cuban Missile Crisis, 1962 / L. Chang, P. Kornbluth (eds.). New York : The New Press, 1992. URL: https://nsarchive2.gwu.edu/nsa/cuba_mis_cri/chron.htm (access date: 02.10.2017).

12. Elsea J., Else D. Naval Station Guantanamo Bay: History and Legal Issues Regarding Its Lease Agreements. URL: https://fas.org/sgp/crs/natsec/R44137.pdf (access date: 28.09.2017).

13. II-49 Address by Roswell L. Gilpatric, Deputy Secretary of Defense, before the Business Council at The Homestead, Hot Springs, VA (October 21, 1961). URL: https://www.cia.gov/library/readingroom/ docs/1961-10-21.pdf (access date: 03.10.2017).

14. Gromyko Telegram to Mikoyan (November 1, 1962). URL: https://nsarchive2.gwu.edu/NSAEBB/ NSAEBB400/docs/1962-11-01\%20Gromyko\%20to\%20Mikoyan.pdf (access date: 29.09.2017).

15. Gromyko Telegram to Mikoyan (November 10, 1962). URL: https://nsarchive2.gwu.edu/NSAEBB/ NSAEBB400/docs/1962-11-10\%20Gromyko\%20to\%20Mikoyan.pdf (access date: 29.09.2017).

16. Gromyko Telegram to Mikoyan (November 18, 1962). URL: https://nsarchive2.gwu.edu/NSAEBB/ NSAEBB400/docs/1962-11-18\%20Gromyko\%20Telegram\%20to\%20Mikoyan.pdf (access date: 29.09.2017).

17. Cuban Missile Crisis: What the World Didn't Know : Interview with Sergo Mikoyan by Sherry Jones. $A B C$ News. 1992. URL: https://nsarchive2.gwu.edu/NSAEBB/NSAEBB400/docs/Interview\%20with\%20 Sergo\%20Mikoyan.pdf (access date: 02.10.2017).

18. Johnson L. U.S. National Security Council, Net Evaluation Subcommittee, Oral Report (August 27 , 1963). URL: https://nsarchive2.gwu.edu/nukevault/special/doc08.pdf (access date: 01.10.2017).

19. Kennedy R.F., Schlesinger A.M. Thirteen days: a memoir of the Cuban missile crisis. New York : W.W. Norton \& Company, 2000. 192 p.

20. Letter from Khrushchev to Castro (October 28, 1962). URL: https://nsarchive2.gwu.edu/nsa/cuba_mis_ cri/19621028khrlet.pdf (access date: 29.09.2017).

21. Letter from Khrushchev to Castro (October 30, 1962). URL: https://nsarchive2.gwu.edu/nsa/cuba_mis_ cri/621030\%20Letter\%20to\%20Castro.pdf (access date: 29.09.2017).

22. Khrushchev S. How My Father and President Kennedy Saved the World. American Heritage. 2002. Vol. 53. Issue 5. P. 66-75.

23. Malinovsky R., Zakharov M. Draft directive to the Commander of Soviet Forces in Cuba on transfer of II-28s and Luna Missiles, and Authority on Use of Tactical Nuclear Weapons (September 8, 1962). URL: https://nsarchive2.gwu.edu/nsa/cuba_mis_cri/620908\%20Memorandum\%20from\%20Malinovsky.pdf (access date: 03.10.2017). 
24. Telegram from Malinovsky to Pliyev (October 22, 1962). URL: https://nsarchive2.gwu.edu/NSAEBB/ NSAEBB449/docs/Doc\%209\%201962.10.22\%20Telegram\%20Trostnik\%20to\%20Pavlov.pdf (access date: 03.10.2017).

25. Telegram from Malinovsky to Pliyev (October 27, 1962). URL: https://nsarchive2.gwu.edu/NSAEBB/ NSAEBB449/docs/Doc\%2011\%201962.10.27\%20Telegram\%20from\%20Trostnik\%20to\%20Pavlov. pdf (access date: 03.10.2017).

26. Telegrams from Malinovsky to Pliyev (circa) (November 5, 1962). URL: https://nsarchive2.gwu.edu/ nsa/cuba_mis_cri/621105\%20Telegrams\%20from\%20Malinovsky.pdf (access date: 03.10.2017).

27. Ciphered Telegram from Mikoyan to CC CPSU (November 6, 1962). URL: https://nsarchive2.gwu.edu/ nsa/cuba_mis_cri/621106\%20Ciphered\%20Mikoyan\%20Telegram.pdf (access date: 03.10.2017).

28. Memorandum of Conversation between Mikoyan and Cuban Leaders (November 5, 1962). URL: https:// nsarchive2.gwu.edu/nsa/cuba_mis_cri/621105\%20MemCon\%20Mikoyan\%20(evening).pdf (access date: 03.10.2017).

29. Memorandum of A.I. Mikoyan's Conversation with Comrades F. Castro, O. Dorticós, E. Guevara, E. Aragonés, and C.R. Rodriguez (November 22, 1962). URL: https://nsarchive2.gwu.edu/ NSAEBB/NSAEBB393/docs/Mikoyan\%20Castro\%20memcon\%2011\%2022\%2062.pdf (access date: 05.10.2017).

30. Mikoyan S., Savranskaya S. The Soviet Cuban missile crisis: Castro, Mikoyan, Kennedy, Khrushchev, and the missiles of November. Washington : Woodrow Wilson Center Press, 2012. 616 p.

31. Vasilev G. A Hedgehog in the Americans' Pants: Thirty Years Since the Caribbean Crisis. The Moscow News (Russia). 1992. October 18. P. 12. 